\title{
DESAIN KONTROL PENGOBATAN PADA MODEL SIRD UNTUK PENYEBARAN VIRUS COVID-19 MENGGUNAKAN BACKSTEPPING
}

\author{
Treatment control design for SIRD Model of Covid-19 Using Backstepping \\ Khozin Mu'tamar ${ }^{1 *}$, Janson Naiborhu' ${ }^{2}$, Roberd Saragih ${ }^{3}$ \\ 1,2,3 Kelompok Keahlian Matematika Industri dan Keuangan, Program Studi Matematika, Fakultas \\ Matematika dan Ilmu Pengetahuan Alam, Institut Teknologi Bandung \\ Jln. Ganesha 10 Bandung 40132, Indonesia \\ Corresponding author email:*1 mutamar.khozin@students.itb.ac.id
}

\begin{abstract}
Abstrak
Pada artikel ini disajikan desain kontrol pada model SIRD dengan pengobatan pada individu yang terinfeksi penyakit. Model SIRD dengan pengobatan diperoleh berdasarkan studi literatur dan parameter model diperoleh dari data kasus harian covid-19 di wilayah provinsi Riau yang diestimasi menggunakan Particle Swarm Optimization. Desain kontrol dilakukan berdasarkan metode backstepping yang dikombinasikan dengan linierisasi umpan balik berdasarkan masukan dan luaran (IOFL). Model SIRD yang merupakan sistem taklinier ditransformasi menjadi bentuk normal menggunakan IOFL. Setiap variabel keadaan selanjutnya distabilkan secara Lyapunov menggunakan virtual kontrol yang sekaligus menghasilkan variabel keadaan yang baru. Tahapan ini akan dilakukan secara iteratif sampai variabel keadaan terakhir yang distabilkan menggunakan fungsi kontrol nyata. Fungsi kontrol ini kemudian diterapkan pada model SIRD menggunakan balikan transformasi IOFL. Hasil simulasi dibandingkan dengan metode Prinsip Minimum Pontryagin (PMP) menunjukkan bahwa dengan pemilihan parameter kontrol backstepping yang tepat dapat menghasilkan performa kontrol yang lebih baik berupa jumlah populasi terinfeksi yang lebih kecil.
\end{abstract}

Kata Kunci : Model epidemi SIRD, Pengobatan, metode backstepping, linierisasi umpan balik berdasarkan masukanluaran, bentuk normal.

\begin{abstract}
In this article, we present a control design on a SIRD model with treatment in infected individuals. The SIRD model with treatment is obtained from literature study and the parameter model is obtained from covid-19 daily case in the Riau province using the Particle Swarm Optimization method. The control design is carried out based on the backstepping method combined with feedback linearization based on input and output (IOFL). The SIRD model which is a nonlinear system will be transformed into a normal form using IOFL. Each variable is then stabilized Lyapunov using virtual control which at the same time generates a new state variable. This stage will be carried out iteratively until the last state variable is stabilized using a real control function. This control function is then applied to the SIRD model using the inverse of IOFL transformation. The simulation results compared with the Pontryagin Minimum Principle (PMP) method show that by selecting the appropriate control parameters, backstepping obtains better control performance which is a smaller number of infected populations.
\end{abstract}

Keywords: Epidemic model SIRD, treatment, backstepping method, input-output feedback linearization, normal form. 


\section{PENDAHULUAN}

Virus covid-19 pertama kali diidentifikasi pada Desember 2019 di Wuhan, Cina [1]. Pada perkembangannya, virus ini terus bermutasi dan memiliki beberapa varian [2]. Beberapa varian terbaru memiliki tingkat infeksi dengan tingkat fatalitas yang tinggi dibandingkan varian di awal penyebaran. Beberapa tahapan untuk mengatasi penyebaran ini adalah melakukan tindakan pencegahan seperti jaga jarak, menjaga kesehatan dan pemberian vaksinasi [3]-[5]. Selain pencegahan, tindakan pengobatan untuk individu yang sudah terinfeksi perlu dilakukan untuk mencegah dampak terburuk virus ini. Efektivitas pengobatan perlu dikembangkan karena ketimpangan dengan kemampuan penyebaran virus dapat mengakibatkan tingkat reservasi yang sangat tinggi pada ruang perawatan rumah sakit.

Salah satu cara menganalisis penyebaran virus covid-19 adalah menggunakan model matematika, salah satunya adalah model SIRD. Model SIRD merupakan akronim dari susceptible yang menyatakan individu sehat, infected yang menyatakan individu terinfeksi, recovered yang menyatakan individu yang telah sembuh, dan death yang menyatakan individu yang meninggal. Model SIRD ini merupakan sistem persamaan diferensial biasa taklinier sehingga analisis kestabilan dilakukan menggunakan hampiran linierisasi ataupun bilangan reproduksi. Meskipun model SIRD adalah model dasar, namun model ini masih bisa digunakan sebagai alat analisis karena kompleksitas model tidak selalu menjamin representasi model tersebut terhadap fenomena [6]. Untuk menganalisis pengaruh pengobatan pada populasi terinfeksi, penggunaan kontrol dapat diterapkan pada model SIRD. Fungsi kontrol disematkan pada variabel yang merepresentasikan individu terinfeksi untuk mengurangi laju penambahan populasi. Desain kontrol yang biasa digunakan adalah kontrol optimum menggunakan Prinsip Minimum Pontryagin (PMP).

Salah satu metode yang dapat digunakan dalam desain kontrol pada sistem kontrol taklinier adalah metode backstepping yang dikembangkan pada awal tahun 1990-an [7], [8] yang banyak diterapkan pada sistem dengan bentuk strict feedback [9]. Metode ini dilakukan secara iteratif dengan melakukan transformasi variabel keadaan dan virtual kontrol di setiap tahapan untuk menjamin kestabilan sistem secara Lyapunov. Penggunaan backstepping sangat luas di berbagai bidang, yang dapat dilihat pada [9]-[12]. Pada artikel ini akan diterapkan desain kontrol pengobatan untuk model epidemi SIRD yang merupakan aspek pembeda utama dengan penelitian yang telah dilakukan sebelumnya. Oleh karena SIRD merupakan sistem taklinier dan umumnya tidak memiliki luaran sistem yang didefinisikan, pada artikel ini didefinisikan luaran sistem yaitu populasi sehat yang akan diarahkan agar mengikuti lintasan yang diinginkan dan transformasi yang digunakan adalah transformasi umpan balik berdasarkan luaran dan masukan. Lintasan yang diinginkan disini berupa nilai konstan yang mewakili jumlah populasi agar populasi sehat tidak terus menurun kurang dari jumlah populasi yang diinginkan. Hal ini sangat jarang dilakukan dalam penggunaan metode PMP pada model epidemi seperti pada [13]-[16].

Artikel ini disusun dengan sistematika berikut. Setelah bagian pendahuluan disajikan metode penelitian yang digunakan. Pada bagian metode penelitian disampaikan tentang prosedur penelitian dan teori dasar yang digunakan dalam penelitian meliputi model SIRD dan linearisasi umpan balik berdasarkan masukan dan luaran (IOFL). Selanjutnya adalah bagian hasil dan pembahasan. Pada bagian ini disajikan beberapa bagian meliputi transformasi model SIRD menjadi bentuk normal, desain kontrol menggunakan metode backstepping dan penerapan menggunakan data kasus harian. Pada akhir artikel diberikan kesimpulan yang merangkum seluruh artikel ini.

\section{METODE PENELITIAN}

Penelitian ini dilakukan berdasarkan studi literatur. Fokus utama penelitian ini adalah menerapkan desain kontrol yang berbeda dengan desain kontrol yang biasa dilakukan pada model epidemi SIRD. Secara garis besar, prosedur penelitian disajikan pada Gambar 1 dan dapat dijelaskan sebagai berikut

1. Objek penelitian adalah sistem dinamik dengan memilih model epidemi SIRD untuk kasus penyebaran virus covid-19. Model ini merupakan model turunan dari model SIR yang sudah umum digunakan untuk menganalisis beberapa masalah penyebaran penyakit dengan memisahkan antara individu yang sembuh dan meninggal. Pada model ini juga dapat ditentukan apakah virus dapat menyebar atau tidak secara langsung melalui bilangan reproduksi. Nilai bilangan reproduksi diperoleh dari nilai parameter model yang diestimasi menggunakan data harian. 
2. Desain kontrol menggunakan backstepping. Desain kontrol backstepping menggunakan variabel keadaan sebagai variabel kontrol virtual dan biasanya diterapkan pada bentuk kanonik pengontrol. Pada penelitian ini, model SIRD ditransformasi ke bentuk normal menggunakan linierisasi berdasarkan umpan balik masukan-luaran (IOFL) agar dapat dikontrol menggunakan metode backstepping. Oleh karena IOFL membutuhkan luaran sistem, dipilih luaran sistem yang mengakibatkan derajat relatif dari sistem sama dengan dimensi sistem sehingga sistem dapat dilinierisasi secara eksak. Selanjutnya, luaran sistem dikontrol untuk mengikuti lintasan yang diberikan, dalam hal ini nilai konstan ataupun titik asal.

3. Simulasi model menggunakan data kasus harian penyebaran covid-19 di Pekanbaru, propinsi Riau. Data ini diambil dari laman resmi dan media sosial Dinas Kesehatan Provinsi Riau untuk periode September - Oktober 2020. Berdasarkan data, diestimasi parameter model SIRD menggunakan metode Particle Swarm Optimization dengan modifikasi. Selanjutnya, dibandingkan antara metode kontrol backstepping dan metode kontrol Prinsip Minimum Pontryagin (PMP) menggunakan beberapa parameter pilihan.

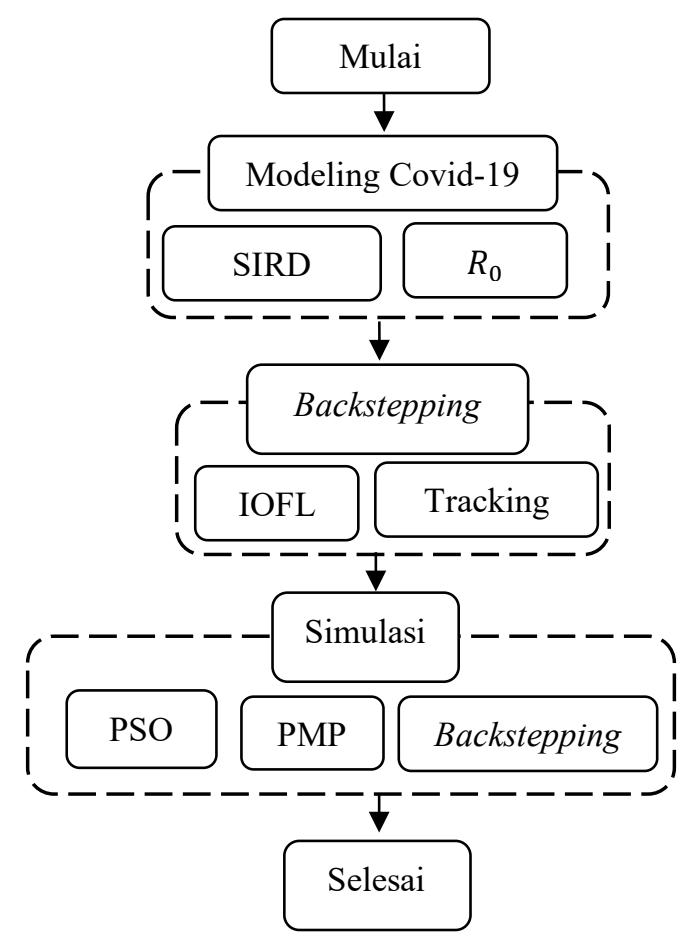

Gambar 1. Diagram proses pelaksanaan penelitian

\subsection{Model Epidemi SIRD}

Model SIRD merupakan akronim dari susceptible (S), infected (I), recovered (R) dan death (D). Susceptible merupakan kelompok individu yang masih sehat namun rentan tertular penyakit. Infected adalah individu yang telah terjangkit penyakit dan belum hilang penyakitnya. Recovered adalah individu yang telah terjangkit penyakit namun penyakitnya telah hilang dengan bentuk kesembuhan, sedangkan death adalah individu yang telah terjangkit penyakit namun penyakitnya telah hilang dalam bentuk kematian. Keempat populasi ini terkumpul dalam satu area yang tertutup sehingga jumlah populasinya tiap waktu selalu konstan. Perubahan status individu dalam kelompok ditunjukkan pada Gambar 2.

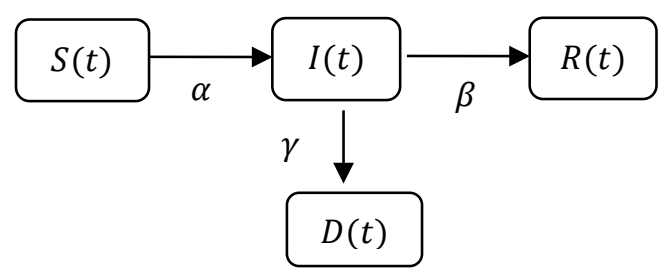

Gambar 2. Skema perubahan status masing-masing kelompok individu 
Secara matematis, persamaan diferensial biasa taklinier yang menyatakan model SIRD dari diagram pada Gambar 2 adalah

$$
\left\{\begin{array}{l}
\frac{d S(t)}{d t}=-\alpha S(t) \frac{I(t)}{N} \\
\frac{d I(t)}{d t}=\alpha S(t) \frac{I(t)}{N}-(\beta+\gamma) \frac{I(t)}{N} \\
\frac{d R(t)}{d t}=\beta \frac{I(t)}{N} \\
\frac{d D(t)}{d t}=\gamma \frac{I(t)}{N}
\end{array}\right.
$$

dengan $N=S(t)+I(t)+R(t)+D(t)$ merupakan total populasi tiap waktu yang nilainya selalu konstan. Didefinisikan perubahan variabel

$$
\left\{s(t)=\frac{S(t)}{N}, i(t)=\frac{I(t)}{N}, r(t)=\frac{R(t)}{N}, d(t)=\frac{D(t)}{N}\right\}
$$

maka persamaan (1) dapat dinyatakan kembali menjadi sistem tanpa dimensi yaitu

$$
\left\{\begin{array}{l}
s^{\prime}(t)=-\alpha s(t) i(t) \\
i^{\prime}(t)=\alpha s(t) i(t)-(\beta+\gamma) i(t) \\
r^{\prime}(t)=\beta i(t) \\
d^{\prime}(t)=\gamma i(t)
\end{array}\right.
$$

dan jumlah populasi total menjadi $s(t)+i(t)+r(t)+d(t)=1$.

Penyebaran populasi akan terjadi jika terpenuhi $\frac{d i(t)}{d t}>0$. Berdasarkan persamaan (2), didapatkan bahwa

$$
\alpha s(t) i(t)-(\beta+\gamma) i(t)>0
$$

Oleh karena $i(t) \neq 0$ dan di awal penyebaran $s(t) \approx 1$ maka didapatkan bilangan reproduksi untuk model SIRD yaitu

$$
R_{0}=\frac{\alpha}{\beta+\gamma}>1
$$

\subsection{Linierisasi Berdasarkan Umpan Balik Masukan-Luaran}

Diberikan sistem kontrol taklinier dengan masukan dan luaran tunggal dalam bentuk:

$$
\left\{\begin{aligned}
\frac{d \mathbf{x}(t)}{d t} & =\mathbf{f}(\mathbf{x})+u(t) \mathbf{g}(\mathbf{x}) \\
y(t) & =h(\mathbf{x}(t))
\end{aligned}\right.
$$

dengan $x \in \square^{n}$ adalah variabel keadaan, $u(t) \in \square$ adalah variabel kontrol, $\mathbf{f}(\mathbf{x}), \mathbf{g}(\mathbf{x}) \in \square^{n}$ fungsi vektor yang mulus pada domain $D \subseteq \square^{n}$, dan $y(t) \in \square$ adalah luaran sistem. Diasumsikan bahwa sistem (4) memiliki derajat relatif $\rho=n$ sehingga memenuhi

$$
\left\{\begin{array}{l}
L_{\mathrm{g}} L_{\mathrm{f}}{ }^{k-1} h(\mathbf{x})=0 \quad, \quad k=1,2, \ldots, \rho-1 \\
L_{\mathrm{g}} L_{\mathbf{f}}{ }^{\rho-1} h(\mathbf{x}) \neq 0,
\end{array}\right.
$$

Didefinisikan transformasi koordinat $\mathbf{z}=\mathbf{T}(\mathbf{x})$ 


$$
\begin{cases}z_{1} & =h(\mathbf{x}) \\ z_{2} & =L_{\mathbf{f}} h(\mathbf{x}) \\ \vdots & \vdots \\ z_{n} & =L_{\mathbf{f}}{ }^{n-1} h(\mathbf{x})\end{cases}
$$

Turunan sistem (5) terhadap waktu akan menghasilkan

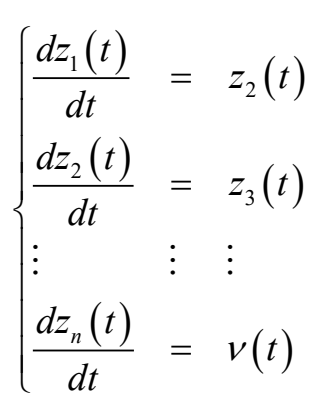

dengan $v(t)=L_{\mathbf{f}}{ }^{n} h(\mathbf{x})+u(t) L_{\mathbf{g}} L_{\mathbf{f}}{ }^{n-1} h(\mathbf{x})$ adalah fungsi kontrol pada sistem (6) dengan koordinat $\mathbf{z}(t)$. Sistem (6) merupakan sistem kontrol linier sehingga desain kontrol $v(t)$ dapat dilakukan dengan berbagai macam teknik yang umum digunakan pada sistem kontrol linier. Nilai kontrol $u(t)$ diperoleh dari hubungannya dengan nilai $v(t)$ dan menggunakan balikan transformasi $\mathbf{z}=\mathbf{T}(\mathbf{x})$.

\section{HASIL DAN PEMBAHASAN}

Pada bagian ini dijelaskan penerapan metode kontrol backstepping pada desain kontrol pengobatan di model SIRD. Selanjutnya, simulasi dilakukan dengan mengambil data kasus harian penyebaran covid-19 di propinsi Riau untuk periode September - Oktober 2020.

\subsection{Linierisasi berdasarkan luaran dan masukan}

Perhatikan model SIRD untuk dua variabel utama, yaitu

$$
\left\{\begin{array}{l}
\frac{d s(t)}{d t}=-\alpha s(t) i(t) \\
\frac{d i(t)}{d t}=\alpha s(t) i(t)-(\beta+\gamma) i(t)-u(t) i(t)
\end{array}\right.
$$

Sistem ini dapat dinyatakan dalam bentuk sistem kontrol taklinier $\dot{\mathbf{x}}=\mathbf{f}(\mathbf{x})+u(t) \mathbf{g}(\mathbf{x})$ dengan

$$
\mathbf{f}(\mathbf{x})=\left[\begin{array}{c}
-\alpha s(t) i(t) \\
\alpha s(t) i(t)-(\beta+\gamma) i(t)
\end{array}\right], \mathbf{g}(\mathbf{x})=\left[\begin{array}{c}
0 \\
i(t)
\end{array}\right]
$$

Jika luaran sistem adalah jumlah populasi sehat $s(t)$ yang akan dibawa ke suatu nilai tertentu, maka selisih antara luaran sistem dan lintasan yang diinginkan diberikan oleh

$$
\left\{\begin{array}{l}
e_{1}(t)=s(t)-y_{d}(t) \\
e_{2}(t)=L_{\mathbf{f}} h(\mathbf{x})-\dot{y}_{d}(t)
\end{array}\right.
$$

Menggunakan persamaan (8), diperoleh $L_{\mathrm{f}} h(\mathbf{x})=\alpha s(t) i(t)$ sehingga dengan menurunkan persamaan (9) diperoleh 


$$
\left\{\begin{array}{l}
\frac{d e_{1}(t)}{d t}=e_{2}(t) \\
\frac{d e_{2}(t)}{d t}=v(t)
\end{array}\right.
$$

dengan $v(t)$ adalah variabel kontrol yang berlaku di sistem (10) dan hubungannya dengan kontrol $u(t)$ diberikan oleh

$$
v(t)=L_{\mathrm{f}}^{2} h(\mathbf{x})+L_{\mathbf{g}} L_{\mathbf{f}} h(\mathbf{x}) u(t)-\ddot{y}_{d}(t)
$$

Oleh karena $L_{\mathrm{f}} h(\mathbf{x})=\alpha s(t) i(t)$ maka didapatkan $L_{\mathbf{f}}{ }^{2} h(\mathbf{x})=-\alpha s(t) i(t)[-\alpha i(t)-\alpha s(t)+\beta+\gamma]$ dan $L_{\mathrm{g}} L_{\mathrm{f}} h(\mathbf{x})=\alpha s(t) i(t)$ sehingga persamaan (11) dapat dituliskan dengan

$$
v(t)=\alpha s(t) i(t)[u(t)+\alpha i(t)+\alpha s(t)-\beta-\gamma]-\ddot{y}_{d}(t)
$$

\subsection{Desain Kontrol Menggunakan Metode Backstepping}

Desain kontrol untuk menstabilkan sistem (10) dimulai dengan menstabilkan variabel $e_{1}(t)$ menggunakan variabel $e_{2}(t)$ sebagai kontrol virtual. Didefinisikan fungsi Lyapunov $V_{1}(t)=\frac{1}{2} e_{1}^{2}(t)$ dan turunannya terhadap waktu menghasilkan

$$
\frac{d V_{1}(t)}{d t}=e_{1}(t) e_{2}(t)
$$

Agar variabel $e_{1}(t)$ stabil asimtotik maka haruslah $\frac{d V_{1}(t)}{d t}<0$ dan dimisalkan $\frac{d V_{1}(t)}{d t}=-r_{1} e_{1}^{2}(t)$ untuk $r_{1} \in \square^{+}$maka didapatkan $e_{2}(t)=-r_{1} e_{1}(t)$. Didefinisikan perubahan variabel keadaan dengan kontrol virtual

$$
w(t)=e_{2}(t)+r_{1} e_{1}(t)
$$

Substitusikan fungsi $w(t)$ persamaan (13) dan turunannya pada persamaan (10) sehingga diperoleh sistem yang baru dalam variabel $\left\{e_{1}(t), w(t)\right\}$

$$
\left\{\begin{array}{l}
\frac{d e_{1}(t)}{d t}=w(t)-r_{1} e_{1}(t) \\
\frac{d w(t)}{d t}=v(t)+r_{1}\left(w(t)-r_{1} e_{1}(t)\right)
\end{array}\right.
$$

Langkah selanjutnya adalah menstabilkan seluruh sistem (14) menggunakan kontrol $v(t)$. Pilih fungsi Lyapunov $V_{2}(t)=\frac{1}{2}\left(e_{1}^{2}(t)+w^{2}(t)\right)$ dan turunannya terhadap waktu menghasilkan

$$
\frac{d V_{2}(t)}{d t}=-r_{1} e_{1}^{2}(t)+w(t)\left[\left(1-r_{1}^{2}\right) e_{1}(t)+r_{1} w(t)+v(t)\right]
$$

Diasumsikan berlaku $\frac{d V_{2}(t)}{d t}=-r_{1} e_{1}^{2}(t)-r_{2} w^{2}(t)$ untuk $r_{2} \in \square^{+}$sehingga dari persamaan (15) didapatkan hubungan

$$
\left(1-r_{1}^{2}\right) e_{1}(t)+r_{1} w(t)+v(t)=-r_{2} w(t)
$$

Substitusikan persamaan (16) pada sistem (14) sehingga diperoleh sistem akhir yang telah distabilkan 


$$
\left\{\begin{array}{l}
\frac{d e_{1}(t)}{d t}=-r_{1} e_{1}(t)+w(t) \\
\frac{d w(t)}{d t}=-e_{1}(t)-r_{2} w(t)
\end{array}\right.
$$

Nilai eigen dari sistem linier persamaan (17) adalah

$$
\lambda=\frac{1}{2}\left[\begin{array}{l}
-\left(r_{1}+r_{2}\right)-\sqrt{r_{1}^{2}-2 r_{1} r_{2}+r_{2}^{2}-4} \\
-\left(r_{1}+r_{2}\right)+\sqrt{r_{1}^{2}-2 r_{1} r_{2}+r_{2}^{2}-4}
\end{array}\right]
$$

Nilai eigen $\lambda_{1}=-\frac{1}{2}\left[\left(r_{1}+r_{2}\right)+\sqrt{r_{1}^{2}-2 r_{1} r_{2}+r_{2}^{2}-4}\right]$ sudah memenuhi $\operatorname{Re}\left(\lambda_{1}\right)<0$ untuk setiap nilai $r_{1}, r_{2} \in \square^{+}$. Agar $\operatorname{Re}\left(\lambda_{2}\right)<0$ diperlukan $-\left(r_{1}+r_{2}\right)+\sqrt{r_{1}^{2}-2 r_{1} r_{2}+r_{2}^{2}-4}<0$ sehingga diperoleh hubungan $r_{1}^{2}-2 r_{1} r_{2}+r_{2}^{2}-4<\left(r_{1}+r_{2}\right)^{2}$ yang berakibat $-1<r_{1} r_{2}$ untuk setiap $r_{1}, r_{2} \in \square^{+}$. Oleh karena $\operatorname{Re}\left(\lambda_{i}\right)<0$ untuk $i=1,2$ maka sistem (17) telah stabil asimtotik secara lokal.

Fungsi kontrol $v(t)$ yang menstabilkan persamaan (10) diperoleh berdasarkan persamaan (16) sehingga didapatkan

$$
v(t)=\left(r_{1}^{2}-1\right) e_{1}(t)-\left(r_{1}+r_{2}\right) w(t)
$$

Berdasarkan transformasi variabel keadaan dan variabel kontrol virtual persamaan (13), kontrol $v(t)$ persamaan (18) dapat dinyatakan

$$
v(t)=-\left[1+r_{1} r_{2}\right] e_{1}(t)-\left(r_{1}+r_{2}\right) e_{2}(t)
$$

Kontrol $u(t)$ yang akan digunakan pada sistem (2) diperoleh berdasarkan hubungan persamaan (12) dengan $v(t)$ menggunakan persamaan (19) sehingga diperoleh

$$
u(t)=-\alpha(i+s)+\beta+\gamma-\left(r_{1}+r_{2}\right)+\frac{1}{i}\left(\frac{r_{2} r_{1}-1}{\alpha}+\frac{\ddot{y}_{d}+\left[r_{1}+r_{2}\right] \dot{y}_{d}-\left[r_{1} r_{2}-1\right] y_{d}}{\alpha s}\right)
$$

Oleh karena $u(t)$ terbatas pada $U=\{u(t) \mid 0 \leq u(t) \leq 1\}$ maka nilai kontrol yang digunakan adalah

$$
u^{*}(t)= \begin{cases}0, & u(t) \leq 0 \\ 1, & u(t) \geq 1 \\ u(t), & \text { lainnya }\end{cases}
$$

dengan $u(t)$ diberikan pada persamaan (20).

\subsection{Penerapan pada penyebaran covid-19 wilayah Pekanbaru, Riau}

Untuk menerapkan kontrol pada model SIRD, digunakan data kasus harian covid-19 di wilayah Pekanbaru, propinsi Riau pada periode September - Oktober 2020. Data kasus harian diberikan pada Tabel 1.

Tabel 1. Data harian kasus Covid-19 di Wilayah Pekanbaru periode September-Oktober 2020

\begin{tabular}{cccccccc}
\hline Tanggal & Positif & Sembuh & Meninggal & Tanggal & Positif & Sembuh & Meninggal \\
\hline $1 / 9$ & 38 & 4 & 1 & $3 / 10$ & 115 & 48 & 5 \\
\hline $2 / 9$ & 47 & 4 & 1 & $4 / 10$ & 114 & 123 & 4 \\
\hline $3 / 9$ & 41 & 8 & 0 & $5 / 10$ & 126 & 150 & 4 \\
\hline $4 / 9$ & 46 & 16 & 5 & $6 / 10$ & 69 & 80 & 3 \\
\hline $5 / 9$ & 69 & 63 & 0 & $7 / 10$ & 84 & 143 & 3 \\
\hline $6 / 9$ & 60 & 69 & 3 & $8 / 10$ & 166 & 58 & 2 \\
\hline $7 / 9$ & 72 & 17 & 1 & $9 / 10$ & 124 & 56 & 2 \\
\hline $8 / 9$ & 87 & 27 & 2 & $10 / 10$ & 117 & 33 & 2 \\
\hline $9 / 9$ & 51 & 25 & 0 & $11 / 10$ & 55 & 24 & 0 \\
\hline $13 / 9$ & 129 & 16 & 5 & $12 / 10$ & 122 & 32 & 1 \\
\hline
\end{tabular}




\begin{tabular}{cccccccc}
\hline Tanggal & Positif & Sembuh & Meninggal & Tanggal & Positif & Sembuh & Meninggal \\
\hline $14 / 9$ & 81 & 9 & 2 & $13 / 10$ & 86 & 12 & 2 \\
\hline $15 / 9$ & 68 & 29 & 3 & $14 / 10$ & 182 & 42 & 4 \\
\hline $16 / 9$ & 94 & 7 & 2 & $15 / 10$ & 93 & 55 & 2 \\
\hline $17 / 9$ & 120 & 7 & 3 & $16 / 10$ & 112 & 37 & 2 \\
\hline $18 / 9$ & 128 & 190 & 2 & $17 / 10$ & 158 & 63 & 3 \\
\hline $19 / 9$ & 190 & 45 & 0 & $18 / 10$ & 150 & 36 & 2 \\
\hline $20 / 9$ & 119 & 77 & 2 & $19 / 10$ & 65 & 421 & 3 \\
\hline $21 / 9$ & 72 & 22 & 2 & $20 / 10$ & 97 & 451 & 1 \\
\hline $22 / 9$ & 152 & 69 & 0 & $21 / 10$ & 153 & 176 & 8 \\
\hline $23 / 9$ & 113 & 38 & 8 & $22 / 10$ & 170 & 115 & 3 \\
\hline $24 / 9$ & 127 & 36 & 5 & $23 / 10$ & 97 & 182 & 2 \\
\hline $25 / 9$ & 122 & 82 & 4 & $24 / 10$ & 215 & 173 & 6 \\
\hline $26 / 9$ & 125 & 110 & 2 & $25 / 10$ & 121 & 383 & 1 \\
\hline $27 / 9$ & 92 & 116 & 3 & $26 / 10$ & 68 & 142 & 2 \\
\hline $28 / 9$ & 152 & 54 & 3 & $27 / 10$ & 112 & 169 & 5 \\
\hline $29 / 9$ & 109 & 84 & 4 & $28 / 10$ & 124 & 131 & 4 \\
\hline $30 / 9$ & 227 & 202 & 5 & $29 / 10$ & 111 & 121 & 5 \\
\hline $1 / 10$ & 158 & 133 & 4 & $30 / 10$ & 71 & 122 & 6 \\
\hline $2 / 10$ & 89 & 22 & 3 & $31 / 10$ & 37 & 105 & 2 \\
\hline
\end{tabular}

Sumber data: Dinas Kesehatan Riau tahun 2020

Parameter model diestimasi menggunakan metode Particle Swarm Optimization (PSO) sesuai dengan prosedur yang diberikan pada [17] dan hasilnya adalah

$$
\{\alpha=0.074625, \beta=0.047901, \gamma=0.004886\}
$$

Bilangan reproduksi berdasarkan persamaan (3) adalah

$$
R_{0}=\frac{\alpha}{\beta+\gamma}=\frac{0.074625}{0.052787}=1.413708
$$

yang menandakan virus covid-19 akan terus menyebar. Selanjutnya, parameter yang digunakan untuk simulasi kontrol diberikan pada Tabel 2.

Tabel 2. Parameter kontrol; backstepping dan kontrol optimal

\begin{tabular}{cccl}
\hline No & Parameter & Nilai & \multicolumn{1}{c}{ Deskripsi } \\
\hline 1 & $\mathrm{r}_{1}$ & $\{0.75,3\}$ & Parameter positif backstepping untuk stabilisasi \\
\hline 2 & $\mathrm{r}_{2}$ & $\{0.5,4\}$ & Paremeter positif backstepping untuk stabilisasi \\
\hline 3 & $\mathrm{q}_{\mathrm{s}}$ & 10 & $\begin{array}{l}\text { Faktor pembobot performa indeks untuk } s(t) \\
\text { pada kontrol optimal }\end{array}$ \\
\hline 4 & $\mathrm{q}_{\mathrm{i}}$ & 10 & $\begin{array}{l}\text { Faktor pembobot performa indeks untuk } i(t) \text { pada } \\
\text { kontrol optimal }\end{array}$ \\
\hline 5 & $y_{d}(t)$ & 0.6 & Nilai akhir yang harus dicapai oleh populasi sehat \\
\hline
\end{tabular}

Berdasarkan nilai Tabel 2, nilai eigen sistem linier (17) adalah

$$
\left\{\lambda_{(0.75,0.5)}=-0.625 \pm 0.99 I, \lambda_{(0.75,4)}=\{-1.0941,-3.6558\}, \lambda_{(3,0.5)}=\{-1,-2.5\}, \lambda_{(3,4)}=-3.5 \pm 0.866\right\}
$$

Berdasarkan nilai eigen ini, populasi dengan kombinasi $\left\{r_{1}, r_{2}\right\}$ kedua hingga keempat akan lebih cepat konvergen ke titik asal. Hal ini mengakibatkan jumlah populasi terinfeksi akan segera menghilang sehingga jumlah populasi konstan akan tetap bertahan di titik yang diinginkan. Perilaku populasi sehat dan terinfeksi dengan pemberian kontrol backstepping persamaan (21) menggunakan kombinasi $\left\{r_{1}, r_{2}\right\}$ yang berbeda ditunjukkan pada Gambar 3. 


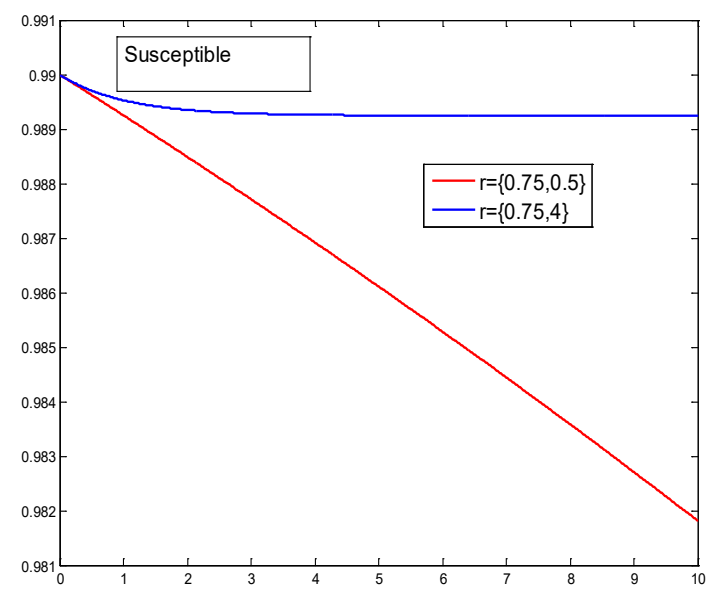

(a)

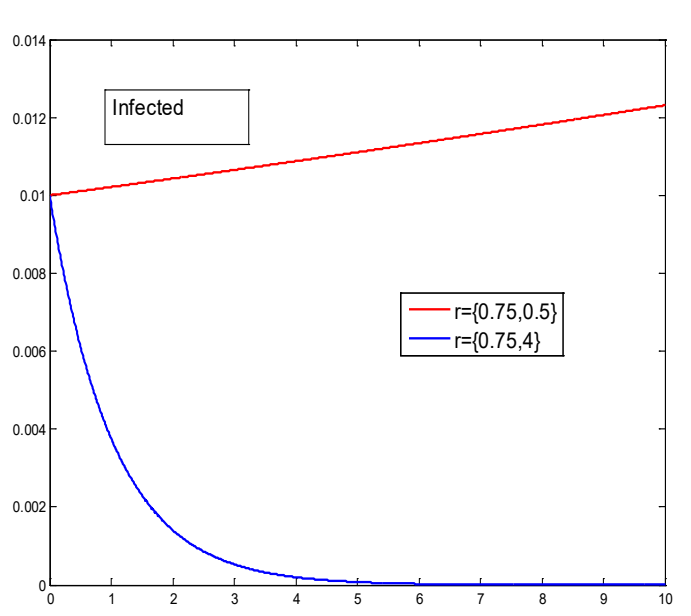

(b)

Gambar 3. Perbandingan performa kontrol berdasarkan nilai kombinasi $\left\{r_{1}, r_{2}\right\}$ yang berbeda (a) populasi sehat (b) populasi terinfeksi

Pada parameter yang rendah $\left\{r_{1}=0.75, r_{2}=0.5\right\}$, kontrol tidak mampu membawa populasi terinfeksi menuju titik asal. Namun, jika performa dinaikkan dengan menaikkan nilai salah satu parameter kontrol, maka populasi terinfeksi dari nilai awal langsung bergerak menuju titik asal. Jumlah populasi sehat dan terinfeksi selama waktu iterasi $t \in[0,10]$ dengan performa kontrol $\left\{r_{1}, r_{2}\right\}$ yang divariasikan disajikan pada Tabel 3 .

Tabel 3. Jumlah populasi pada interval waktu $t \in[0,10]$ dengan variasi $\left\{r_{1}, r_{2}\right\}$

\begin{tabular}{cllcc}
\hline Kombinasi & $\boldsymbol{r}_{\mathbf{1}}$ & $\boldsymbol{r}_{\mathbf{2}}$ & $\boldsymbol{s}(\boldsymbol{t})$ & $\boldsymbol{i}(\boldsymbol{t})$ \\
\hline 1 & 0.75 & 0.5 & 0.98604 & 0.01112 \\
\hline 2 & 0.75 & 4 & 0.98932 & 0.00103 \\
\hline 3 & 3 & 0.5 & 0.98932 & 0.00103 \\
\hline 4 & 3 & 4 & 0.98932 & 0.00103 \\
\hline
\end{tabular}

Nilai jumlah populasi diperoleh dengan cara menghitung nilai $\int_{0}^{t} x(t) d t$ secara numerik menggunakan metode Simpson. Pada Tabel 3, seluruh kombinasi selain kombinasi pertama memiliki performa yang identik. Oleh karena itu, dilakukan juga simulasi untuk interval waktu yang panjang untuk $t \in[0,300]$ dengan seluruh pengaturan yang identik. Hasil dari simulasi untuk $t \in[0,300]$ ditunjukkan pada Gambar 4 dengan jumlah populasi diberikan pada Tabel 4 . Hasil untuk $t \in[0,300]$ menunjukkan bahwa kombinasi dengan performa rendah mengakibatkan penambahan populasi terinfeksi yang tinggi. Meskipun demikian, oleh karena kontrol didesain untuk membawa luaran $s(t)$ mengikuti lintasan yang diinginkan yaitu $s_{d}(t)=0.6$ maka pada interval waktu $t \approx 170$, jumlah populasi terinfeksi diturunkan menuju nol dan populasi sehat dipertahankan pada lintasan yang diinginkan.

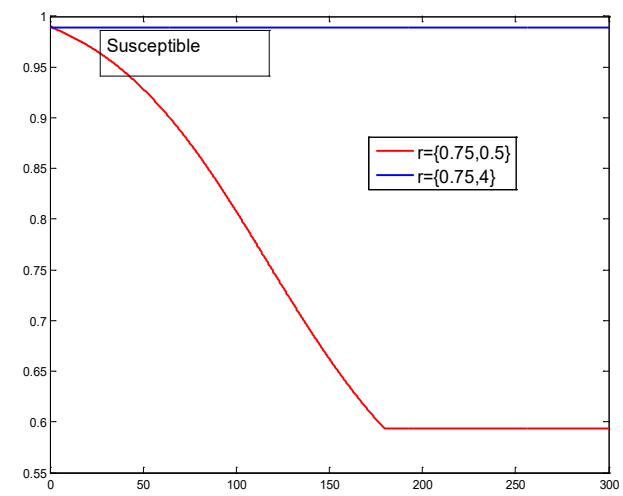

(a)

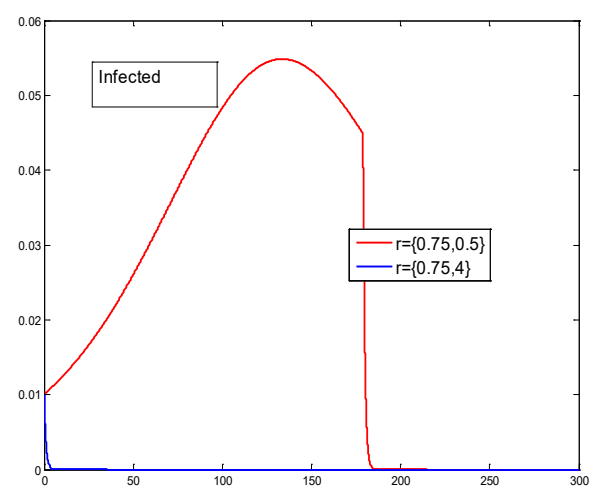

(b)

Gambar 4. Perbandingan performa kontrol berdasarkan nilai kombinasi $\left\{r_{1}, r_{2}\right\}$ yang berbeda (a) populasi sehat mengikuti lintasan $y_{d}$ yang diberikan (b) populasi terinfeksi 
Tabel 4. Jumlah populasi pada interval waktu $t \in[0,300]$ dengan variasi $\left\{r_{1}, r_{2}\right\}$

\begin{tabular}{cllcc}
\hline Kombinasi & $\boldsymbol{r}_{\mathbf{1}}$ & $\boldsymbol{r}_{\mathbf{2}}$ & $\boldsymbol{s}(\boldsymbol{t})$ & $\boldsymbol{i}(\boldsymbol{t})$ \\
\hline 1 & 0.75 & 0.5 & 0.72833 & 0.02288 \\
\hline 2 & 0.75 & 4 & 0.98925 & 0.00003 \\
\hline 3 & 3 & 0.5 & 0.98925 & 0.00003 \\
\hline 4 & 3 & 4 & 0.98925 & 0.00003 \\
\hline
\end{tabular}

Terakhir, dilakukan perbandingan simulasi antara metode kontrol backstepping dengan metode Prinsip Minimum Pontryagin dengan mengikuti prosedur pada [14], [18]. Misalkan dipilih performa indeks

$$
J=\frac{1}{2} \int_{0}^{t} q_{s} s(t)+q_{i} i(t)+q_{r} u(t)^{2} d t
$$

dengan $q_{s}, q_{i}, q_{r} \in \square^{+}$adalah nilai pembobot pada fungsional performa indeks. Kontrol optimum untuk masalah ini adalah

$$
u(t)=\frac{1}{q_{r}} \lambda_{i} i(t)
$$

Fungsi $\left\{\lambda_{s}, \lambda_{i}\right\}$ adalah persamaan costate yang diberikan oleh

$$
\left\{\begin{array}{l}
-\frac{d \lambda_{s}}{d t}=q_{s}-\alpha i(t)\left[\lambda_{s}-\lambda_{i}\right] \\
-\frac{d \lambda_{i}}{d t}=q_{i}-\alpha s(t)\left[\lambda_{s}-\lambda_{i}\right]-\lambda_{i}(\beta+\gamma)-u(t)
\end{array}\right.
$$

dengan nilai batas $\left\{\lambda_{s}\left(t_{f}\right)=0, \lambda_{i}\left(t_{f}\right)=0\right\}$. Untuk mendapatkan nilai $u(t)$ pada persamaan (23) diperlukan dua tahapan yaitu menyelesaikan persamaan (7) dan persamaan (24) sekaligus dengan nilai awal dan nilai batas yang diberikan. Perbandingan kedua metode kontrol pada masalah ini ditunjukkan pada Gambar 5 dan Gambar 6. Tampak pada Gambar 5 bahwa metode backstepping memberikan beberapa hasil berbeda. Jika dilakukan dengan pemilihan parameter kontrol yang tepat maka metode backstepping dapat memberikan performa yang lebih baik, sedangkan jika parameter kontrol kurang mendukung akan mengakibatkan performa kontrol yang lebih buruk dibandingkan PMP. Meskipun demikian, pengaturan performa pada metode backstepping lebih mudah dilakukan karena cukup dengan memilih parameter kontrol dan tidak memerlukan proses solusi iteratif seperti halnya metode PMP. Selain itu, pada Gambar 5.a, meskipun performa awal kontrol backstepping lebih buruk dibandingkan PMP, tapi pada Gambar 5.b untuk interval waktu yang panjang, jumlah populasi sehat dapat diatur sehingga mengikuti lintasan yang sudah diberikan dengan nilai yang dapat diatur agar dapat lebih tinggi dibandingkan nilai final dari PMP.

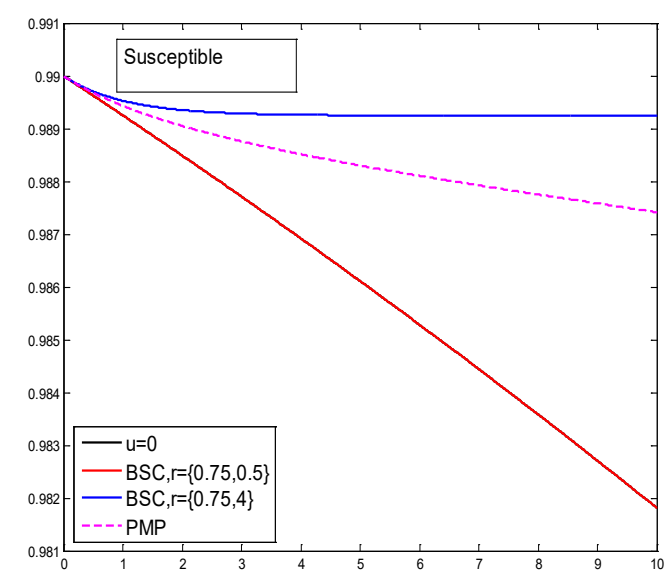

(a)

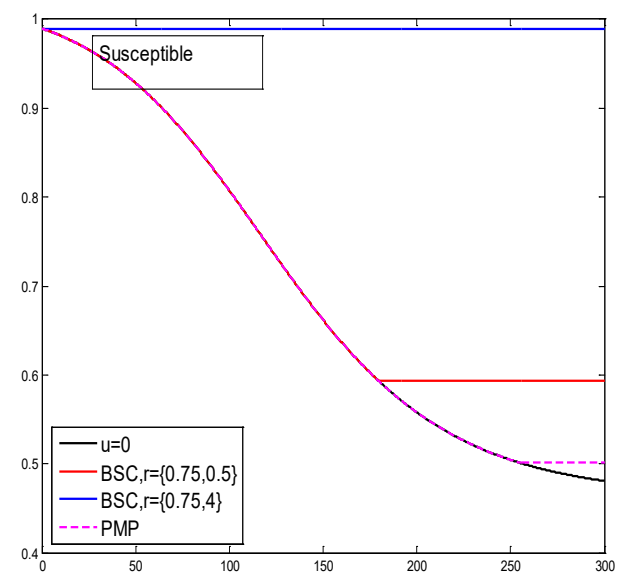

(b)

Gambar 5. Perbandingan dinamika populasi sehat dengan pemberian kontrol untuk metode kontrol yang berbeda (a) $t \in[0,10]$ (b) $t \in[0,300]$ 


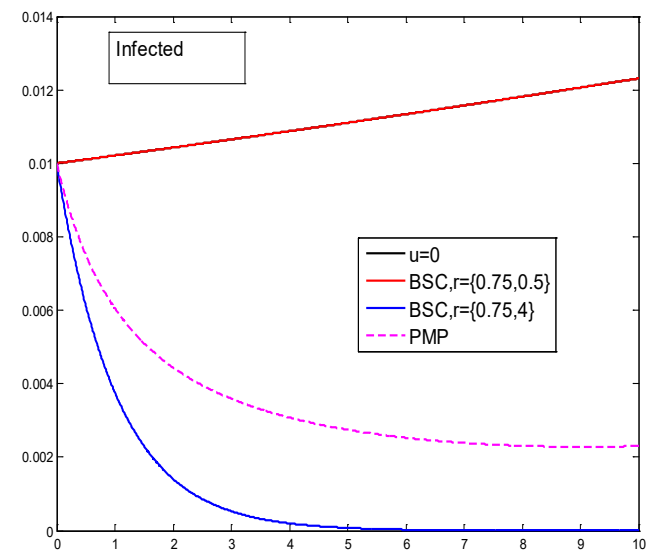

(a)

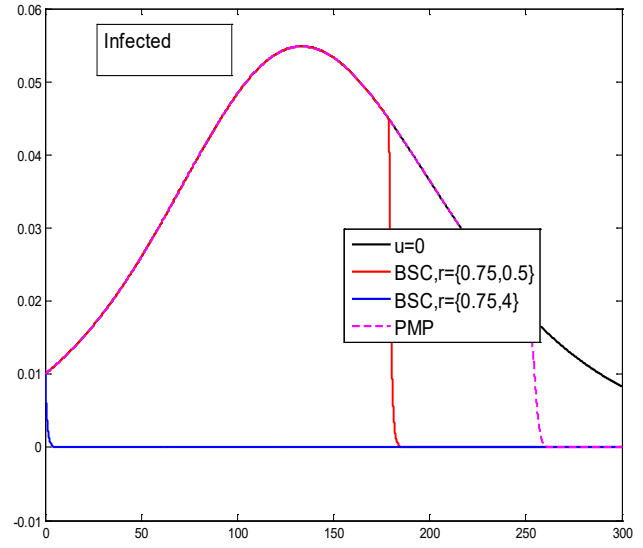

(b)

Gambar 6. Perbandingan dinamika populasi terinfeksi dengan pemberian kontrol untuk metode kontrol yang berbeda (a) $t \in[0,10]$ (b) $t \in[0,300]$

\section{KESIMPULAN}

Pada artikel ini telah disajikan desain kontrol untuk pemberian pengobatan pada model SIRD untuk menganalisis penyebaran virus covid-19. Parameter model diperoleh menggunakan metode particle swarm optimization berdasarkan data kasus harian di wilayah Pekanbaru, Riau selama dua bulan. Desain kontrol pengobatan menggunakan metode backstepping yang dilakukan bertahap dengan mentransformasi model SIRD menjadi bentuk normal. Kontrol backstepping diperoleh berdasarkan bentuk normal dan diterapkan pada model SIRD menggunakan balikan transformasi linierisasi berdasarkan masukan-luaran. Berdasarkan simulasi menggunakan data lapangan, diperoleh nilai $R_{0}>1$ yang berarti bahwa virus covid-19 dapat menyebar. Menggunakan beberapa kombinasi parameter kontrol backstepping disimpulkan bahwa pemilihan parameter ini sangat mempengaruhi performa kontrol. Pada parameter dengan performa yang rendah, kontrol pelacakan tetap berhasil ditandai dengan populasi sehat yang dapat dijaga pada jumlah yang diinginkan. Dari simulasi juga dapat disimpulkan bahwa pengaturan performa kontrol cukup dilakukan dengan memilih parameter kontrol. Terakhir, jika dibandingkan dengan metode Prinsip Minimum Pontryagin, didapatkan bahwa untuk nilai parameter kontrol tertentu, performa kontrol backstepping dapat lebih baik dibandingkan metode PMP. Meskipun performa backstepping lebih buruk dibandingkan PMP, metode backstepping dapat membuat luaran sistem berada pada nilai yang sudah ditentukan yang nilainya lebih tingi dibandingkan metode PMP. Hal ini dapat menjadikan metode backstepping sebagai salah satu alternatif dalam desain kontrol di model epidemi

\section{UCAPAN TERIMA KASIH}

Ucapan terima kasih disampaikan kepada LPPM ITB atas pendanaan Riset tahun 2021. Juga disampaikan terima kasih kepada pada seluruh Reviewer atas masukan untuk perbaikan penyajian artikel ini.

\section{DAFTAR PUSTAKA}

[1] Y. Li $d k k$., "Mathematical Modeling and Epidemic Prediction of COVID-19 and Its Significance to Epidemic Prevention and Control Measures," vol. 5, no. 1, hlm. 9, 2020.

[2] W. Zhou dan W. Wang, "Fast-spreading SARS-CoV-2 variants: challenges to and new design strategies of COVID-19 vaccines," Signal Transduct. Target. Ther., vol. 6, no. 1, hlm. 226, Des 2021, doi: 10.1038/s41392-021-00644-x.

[3] Y. Ophinni $d k k$., "COVID-19 Vaccines: Current Status and Implication for Use in Indonesia," Acta Med Indones, vol. 52, no. 4, hlm. 25, 2020.

[4] F. P. Polack $d k k$., "Safety and Efficacy of the BNT162b2 mRNA Covid-19 Vaccine," N. Engl. J. Med., vol. 383, no. 27, hlm. 2603-2615, Des 2020, doi: 10.1056/NEJMoa2034577.

[5] E. Ong, M. U. Wong, A. Huffman, dan Y. He, "COVID-19 coronavirus vaccine design using reverse vaccinology and machine learning," Bioinformatics, preprint, Mar 2020. doi: 10.1101/2020.03.20.000141. 
[6] W. C. Roda, M. B. Varughese, D. Han, dan M. Y. Li, "Why is it difficult to accurately predict the COVID-19 epidemic?," Infect. Dis. Model., vol. 5, hlm. 271-281, 2020, doi: 10.1016/j.idm.2020.03.001.

[7] J. Zhou dan C. Wen, Adaptive Backstepping Control of Uncertain Systems Nonsmooth Nonlinearities, Interactions or TimeVariations. Heidelberg: Springer, 2008.

[8] H. G. Tanner dan K. J. Kyriakopoulos, "Backstepping for nonsmooth systems," Automatica, vol. 39, no. 7, hlm. 1259-1265, Jul 2003, doi: 10.1016/S0005-1098(03)00081-5.

[9] A. Witkowska dan R. S̀mierzchalski, "Nonlinear backstepping ship course controller," Int. J. Autom. Comput., vol. 6, no. 3, hlm. 277-284, Agu 2009, doi: 10.1007/s11633-009-0277-2.

[10] D. Bresch-Pietri, J. Chauvin, dan N. Petit, "Adaptive backstepping controller for uncertain systems with unknown input timedelay. Application to SI engines," dalam 49th IEEE Conference on Decision and Control (CDC), Atlanta, GA, USA, Des 2010, hlm. 3680-3687. doi: 10.1109/CDC.2010.5717253.

[11] V. Mañosa, F. Ikhouane, dan J. Rodellar, "Control of uncertain non-linear systems via adaptive backstepping," J. Sound Vib., vol. 280, no. 3-5, hlm. 657-680, Feb 2005, doi: 10.1016/j.jsv.2003.12.033.

[12] D. Karagiannis dan A. Astolfi, "Nonlinear adaptive control of systems in feedback form: An alternative to adaptive backstepping," Syst. Control Lett., vol. 57, no. 9, hlm. 733-739, Sep 2008, doi: 10.1016/j.sysconle.2008.02.006.

[13] G. G. Alcaraz dan C. Vargas-De-Leon, "Modeling control strategies for influenza A H1N1 epidemics: SIR models," hlm. 7, 2012.

[14] K. Mu'tamar, “Optimal Control Strategy for Alcoholism Model with Two Infected Compartments,” J. Math., vol. 14, no. 3, hlm. 58-67, 2018.

[15] E. V. Grigorieva, P. B. Deignan, dan E. N. Khailov, "OPTIMAL CONTROL PROBLEM FOR A SEIR TYPE MODEL OF EBOLA EPIDEMICS,” Rev. Matemática Teoría Apl., vol. 24, no. 1, hlm. 79, Jan 2017, doi: 10.15517/rmta.v24i1.27771.

[16] A. Ali Lashari, "Optimal Control of an SIR Epidemic Model with a Saturated Treatment," Appl. Math. Inf. Sci., vol. 10, no. 1, hlm. 185-191, Jan 2016, doi: 10.18576/amis/100117.

[17] S. Putra, K. Mu'tamar, dan Zulkarnain, "Estimation of Parameters in the SIR Epidemic Model Using Particle Swarm Optimization," Am. J. Math. Comput. Model., vol. 4, no. 4, hlm. 83, 2019, doi: 10.11648/j.ajmcm.20190404.11.

[18] K. Mu'tamar, D. Rahmalia, dan Sutimin, "Vaksinasi dan Treatment pada Predator-Prey dengan Dua Jenis Pemangsa yang Salah Satunya Terinfeksi," EKSAKTA J. Sci. Data Anal., hlm. 128-142, Agu 2019, doi: 10.20885/eksakta.vol19.iss2.art4. 